\title{
A COMPARISON OF THE UK STANDARD ASSESSMENT PROCEDURE (SAP) AND DETAILED SIMULATION OF SOLAR ENERGY SYSTEMS FOR DWELLINGS
}

\author{
Murphy, G B ${ }^{1}$, Kummert $\mathrm{M}^{1,2}$, Anderson B R ${ }^{3}$ and Counsell $\mathrm{J}^{1}$ \\ ${ }^{1}$ ESRU, Department of Mechanical Engineering, \\ University of Strathclyde, Glasgow, Scotland \\ ${ }^{2}$ current affiliation: École Polytechnique de Montréal, Department of Mechanical \\ Engineering, Montréal (QC), Canada \\ ${ }^{3}$ Building Research Establishment Scotland, \\ East Kilbride, Glasgow, Scotland
}

Gavin Bruce Murphy, gavin.murphy@strath.ac.uk +44 1415483024

\begin{abstract}
:
The drive to reduce worldwide Carbon Emissions directly associated with dwellings and to achieve a zero carbon home dictates that Renewable Energy Technologies will have an increasingly large role in the built environment. Created by the Building Research Establishment (BRE), the Standard Assessment Procedure (SAP) is the UK Government's approved methodology for assessing the energy ratings of dwellings.
\end{abstract}

This paper presents an evaluation of the advantage given to SAP ratings by the domestic installation of typical Photovoltaic (PV) and Solar Domestic Hot Water (SDHW) systems in the UK. Comparable PV and SDHW systems will also be simulated with more detailed modelling packages.

Results suggest that calculation variances can exist between the SAP methodology and detailed simulation methods, especially for higher performance systems that deviate from the default efficiency parameters.

Keywords: Standard Assessment Procedure (SAP), PV, Solar Domestic Hot Water (SDHW), PVSyst, TRNSYS

\section{INTRODUCTION}

As Governments around the world look to increase the energy efficiency of dwellings for a multitude of reasons such as health factors, regulatory compliance and mitigating climate change, the accuracy of the methodology employed to assess the energy performance of dwellings becomes imperative. In Europe, the European Directive on the Energy Performance of Buildings (Official Journal of the European Communities, 2003), referred to as the Energy Performance of Buildings Directive (EPBD) stipulates that all European member states must produce an Energy Performance Certificate (EPC) and make this available to the next prospective occupier. In 2003 when the EPBD entered into force, only 
the UK, France, The Netherlands, Ireland and Luxembourg had a complete Energy Ratings System (European Commission, 2006). Other European countries had various degrees of Energy Rating Systems whilst Austria, Spain, Finland, Portugal and Sweden had no official building energy rating system (European Commission, 2006). The Energy Rating of Dwellings in the European Union has been researched previously to highlight the many different methodologies utilised throughout Europe to assess the Energy Performance of Dwellings (Míguez et al, 2004). Energy rating systems for dwellings are now becoming more prevalent in other parts of the world. The recent adoption by ASHRAE of the Building Energy Quotient Program - Advanced Building Energy Labelling (Jarnagin et al, 2009), illustrates the relevance of simplified assessment methods in the United States of America. The Building Energy Quotient Program is very similar to European EPCs and offers an update on the information and detail which can be recorded in the Energy Star labelling program (McWhinney et al, 2005). In the UK, SAP is the procedure used to generate an EPC. For the purposes of this research, SAP is the exemplar European simplified methodology selected for this comparison with detailed methodologies. The results found will be applicable to other countries, especially those in Europe which have procedures similar to SAP. The UK SAP Model has been adopted by the Republic of Ireland (DEAP, 2008) and Cyprus (Davidson, 2009). SAP is the UK Government's Standard Assessment Procedure for calculation of a dwelling's energy efficiency and carbon emissions. SAP 2005 is used to demonstrate compliance under the Section 6 (Scotland), Part L (England and Wales) and Part F (Northern Ireland) building regulations. SAP is also the UK Government's approved National Calculation Methodology (NCM) for the assessment of dwellings under the European Directive on the Energy Performance of Buildings (EPBD). In addition to this verification of the SAP methodology, SAP certification has been required on all new UK dwellings since 1995 (SAVE, 2001). Whenever a UK dwelling is constructed, sold or rented, 
the SAP methodology must be employed to calculate ratings for Energy Efficiency and Environmental Impact.

Recent research (Syed et al 2007) clarifies the benefit that PV offers to the residential sector; even in northerly situated countries. Domestic and distributed PV systems account for more than $75 \%$ of the $7.8 \mathrm{GWp}$ installed in IEA PVPS countries at the end of 2007 (IEAPVPS, 2007). Domestic solar thermal applications represent the biggest portion of installed solar heat capacity (128 GWth) and produced energy (77 TWh) (Weiss et al., 2008). This is especially important given that recent studies demonstrate that a third of total domestic energy load of a new dwelling can be attributed to water heating (Ren et al 2007). This underscores the importance for building regulations and energy rating procedures such as SAP to represent accurately the benefits of solar thermal and photovoltaic systems.

SAP is based on the Building Research Establishment Domestic Energy Model-12 (Anderson et al, 2001), known as BREDEM 12. SAP calculates the energy performance of a dwelling based upon Steady State principles where temperatures and heat flow are independent of time (Hens, 2007). The challenge represented by this method is the creation of appropriate definitions of constant factors for parameters such as $\mathrm{U}-$ Values. SAP is based on a 2 zone model as defined in BREDEM, with zone 1 being the living area of the home and zone 2 the bedrooms. BREDEM defines the lower limit of heating these areas to be $21^{\circ} \mathrm{C}$ and $18^{\circ} \mathrm{C}$ for 2 heating profiles, covering the weekday and weekend. Some coefficients in SAP are empirical and derived from extensive studies; the background to the BREDEM / SAP methodology has been researched in depth (Shorrock and Anderson, 1995). The SAP methodology used to assess the energy performance of buildings is based on simple physical equations and empirical evidence; this is also true for the assessment of building- 
integrated solar thermal and photovoltaic systems. The UK government has recognised the requirement for SAP to accurately model low and zero carbon technologies (DCLG, 2007). The SAP methodology has been compared to detailed simulation for low-energy buildings (Cooper, 2008). This study found discrepancies for low energy dwellings and the benefits of some passive solar features. To the authors' knowledge there is no research which directly compares the SAP methodology for PV and SDHW with more detailed assessment methods. This paper seeks to address this situation by investigating the comparison of SAP methodology calculations with more detailed assessment methods.

\section{OBJECTIVE}

This paper aims to compare the PV and SDHW calculations in the SAP methodology with more detailed methods of analysis. It is split into three main sections. The first section will detail a series of Case Studies where comparisons are made between the SAP results for PV and a more detailed numerical simulation of various domestically installed PV systems. The second will measure a standard UK installation of a SDHW system in both SAP and a more detailed analysis. The third will preliminarily assess and simulate a case study of a BRE Innovation Park dwelling incorporating both PV and SDHW.

\section{SOFTWARE TOOLS}

There are a number of different software tools available, some commercially, to assist with the calculation of a SAP rating for a dwelling. The SAP software selected to calculate SAP ratings for this research was designed in house by BRE. This software was used to derive a SAP rating for a defined Standard Test Case building. The software calculated the SAP rating and Carbon Dioxide emissions, of the Standard Test Case Dwelling, according to the 
SAP worksheet. Commercially available BRE approved SAP 2005 calculation tools are available. SAP calculates ratings for Energy Efficiency (EE) and Environmental Impact (EI), usually in the range of 1 to 100 although higher values are possible. The higher the score, the more energy efficient the home is and the less impact the home will have on the environment. The ratings are grouped into alphabetised bandings, as detailed in Figure 1; 1-20=G, 21$38=\mathrm{F}, 39-54=\mathrm{E}, 55-68=\mathrm{D}, 69-80=\mathrm{C}, 81-91=\mathrm{B}, 92$ and over $=\mathrm{A}$. Figure 1 details an example of SAP derived Energy Efficiency and Environment Impact Ratings, as applicable to Scotland. This constitutes an important part of the Energy Performance Certificate (EPC) for the UK as required by the European Performance of Buildings Directive (Directive 2002/91/EC). In the UK, there are subtle differences between the devolved administrations (such as the Scottish Government) in relation to dwelling assessment and so Energy Efficiency and Environmental Impact Ratings produced by SAP will state Scotland, England and Wales or Northern Ireland. This will clarify where that dwelling is located and where ratings are applicable. In other European countries, where the EPBD also applies similar Energy Efficiency Ratings are produced by various tools (Deutsche Energie-Agentur, 2009; Lausten, 2005; DIAG, 2010; Dyrbol and Aggerholm, 2008; Schüle, 2009).

Figure 1. Sample SAP derived Energy Efficiency and Environmental Impact Ratings.

For the sake of conciseness, only EE ratings are discussed in this text and they are referred to as "SAP ratings".

PVSyst is PC oriented software which can be used to simulate, analyse and study various PV systems. PVSyst can simulate PV systems in grid connected, stand alone, pumping or DC grid connected scenarios. During this research, only grid connected systems were considered and analysed. PVSyst performs a detailed simulation in hourly values and 
uses this to provide a PV generation figure in $\mathrm{kWh} /$ year for each PV system modelled. PVSyst allows for different weather profiles to be entered based upon either the Meteonorm standard or TMY (Typical Meteorological Year) files. The development of PVSyst was assisted by the IEA PVPS Task 7 (Schoen et al, 1998).

For the purposes of this research, PVSyst was employed as the detailed simulation tool to model building integrated PV systems. PVSyst is an assessment and benchmarking tool used by PV industry professionals (Lyle, 2009) and PV researchers (Wittchen, 2003).

The TRNSYS 16 Simulation Engine was selected as the detailed SDHW modelling tool for this paper. TRNSYS has been commercially available since 1975 and is a transient systems simulation program (Duffy et al, 2009). During this research TRNSYS was selected as the dynamic simulation package to model SDHW due to the software offering a great flexibility in selecting the assumptions for system configuration, controls, and component parameters and therefore allowing SAP to be compared accurately. TRNSYS has also been validated by users against other simulation tools and experimental data (Kummert et al, 2004). TRNSYS also has a component for the modelling of a whole dwelling, TRNBUILD, which would be useful in modelling renewable systems which have more closely linked to the building, such Heat Pumps. Recent work has seen links with TRNSYS to Google's SketchUp application (Murray et al, 2009).

TRNSYS is referenced in British and European Standards, such as EU ENV-12977-2, for Solar Thermal Systems, and was used as the reference tool in several projects of the International Energy Agency's Solar Heating and Cooling Programme (Perers and Bales, 2002). 


\section{METHODOLOGY}

A Standard Test Case (STC) dwelling was initially modelled in SAP. The STC is detached dwelling with dimensions detailed in Table 1.

SAP v9.82 was used to produce the SAP ratings. A detached house with a total floor area of $104 \mathrm{~m}^{2}$ was modelled. This house is part of a set of BRE developed archetypes to represent the existing building stock. Dimensions, openings and U-Value ratings in $\mathrm{W} / \mathrm{m} 2 \mathrm{~K}$ are recorded in Table 1. Thermal Bridging was recorded and set at the SAP default of $0.15 *$ Total Area of Elements $(247 \mathrm{~m} 2)$ and was calculated to be $37.05 \mathrm{~W} / \mathrm{K}$. Double Glazing with a U-Value of $2.10 \mathrm{~W} / \mathrm{m} 2 \mathrm{~K}$ was modelled with standard external Solid Timber doors embracing a U-Value of $3.00 \mathrm{~W} / \mathrm{m} 2 \mathrm{~K}$. A space and water heating system typical of that installed in a standard dwelling in the UK was modelled in SAP. An air change rate of $15 \mathrm{~m} 3 /$ hour.m2 at 50 Pascals was assumed with a natural ventilation system including 2 intermittent extract fans. $50 \%$ energy efficient lighting was also assumed. A Regular Gas Boiler with an efficiency of 90.2\% (GASTEC, 2010), an Ariston Clas HE R 18, was modelled. The controls for the boiler were recorded as a programmer and at least two room thermostats. The controllability of a system has the effect in SAP of altering the difference in temperature between SAP zones, based upon a calculated Heat Loss Parameter. The Ariston Clas HE R 18 boiler was modelled to supply a stored water system which was sized at 300 litres, of which 180 litres was dedicated to solar storage. A secondary heating system was also modelled in the STC dwelling, standard electric room heaters. These are commonly installed in the UK and were modelled to reflect the standard nature of this dwelling - the addition of direct acting electric heaters to the SAP calculation results in a decreased SAP score, due to the increased use of electricity. This Standard Test Case dwelling modelled in SAP achieves a SAP rating of $\mathrm{C}$ 72. The SAP produced Energy Performance Certificate also provides 
suggestions of improvements which are specific to each dwelling modelled. In the case of the STC dwelling, the following suggestions were made to improve the Energy Efficiency and Environmental Impact of the home: 100\% Low Energy Lighting, addition of Solar Water Heating and Solar Photovoltaic (PV) panels.

Table 1. STC Dwelling SAP Input Listings

\section{PV SIMULATION}

The modelled PV system has a peak power of $2 \mathrm{kWp}$, which is a typical value for a commonly installed PV system in the UK (Energy Saving Trust, 2009). A $2 \mathrm{kWp}$ system could provide approximately $50 \%$ of the average household's electricity; based upon a typical annual electricity consumption of $2500 \mathrm{kWh}$ for a three bed-roomed property (Bahaj and James, 2006). The addition of a PV array with a peak power output of $2 \mathrm{kWp}$ improved the SAP rating from $\mathrm{C} 72$ to $\mathrm{B} 81$. The SAP calculation used to calculate the amount of generated electricity is described below.

\section{SAP calculation to determine $\mathrm{kWh} /$ year - PV}

In SAP v9.82 the following calculation is used to determine the available energy at inverter output in $\mathrm{kWh} /$ year produced by a PV system:

Electricity Produced by the PV Module $=0.80 * \mathrm{kWp} * \mathrm{~S} * \mathrm{Z}_{\mathrm{PV}}$

Where: 


$\begin{array}{lll}0.80 & - & \text { SAP empirical factor for PV } \\ \mathrm{S} & - & \text { Annual solar radiation } \\ \mathrm{Z}_{\mathrm{PV}} & - & \text { shading factor }\end{array}$

The SAP empirical factor for PV of 0.80 cannot be altered by the users of SAP and therefore is comprised of the typical efficiencies for important factors in determining the output of PV systems, such as DC to AC inverters. The SAP empirical factor of 0.80 for PV is an example of a 'SAP Typical' factor. A SAP typical factor is a figure comprised of fair averages for components which have an effect on the SAP rating. A SAP Typical factor is pre-defined by the SAP Methodology and cannot be altered by a SAP Assessor.

Details from SAP Table H2 (Table 2) are used in SAP for the purposes of calculating the system output energy of a PV system. These values are tabulated for Sheffield, which was selected by SAP designers as the nominal centre of the UK. Using one reference weather location allows for dwellings throughout the UK to be compared directly.

Table 2. SAP Table H2 - Annual Solar Radiation, $\mathrm{kWh} / \mathrm{m}^{2}$.

For a $2 \mathrm{kWp}$ system installed in the STC, south facing with no shading with a collector tilt of $30^{\circ}$, the SAP calculated available energy, at the inverter output is $1667 \mathrm{kWh} /$ year. 


\section{Use of PVSyst to determine $\mathrm{kWh} /$ year}

To compare the SAP results directly with the results from PVSyst, the location of Sheffield, UK was taken with a PV system of $2 \mathrm{kWp}$. Weather data for Sheffield, UK is not included with PVSyst by default but it was imported into the software, using a data file from Meteonorm (Meteotest, 2009). An SMA Sunny Boy 2100TL 2.0 kW inverter was selected with an array of 10 Kyocera KC 200GHT-2 Polycrystalline $200 \mathrm{Wp}$ PV modules, to represent components typically installed in the UK (Lyle, 2009). The modules were connected according to the voltage requirements of the inverter and all default PVSyst options were kept. No shading was assumed. The PVSyst-calculated output was $1632 \mathrm{kWh} /$ year, which can be directly compared to the SAP figure of $1667 \mathrm{kWh} /$ year. The $2 \%$ difference between SAP and PVSyst results had no significant effect to the SAP rating, which remained at B 81 for the STC.

\section{Effect of PV components on SAP rating}

SAP allows for the modelling of a generic PV system based upon the peak power in $\mathrm{kWp}$. PVSyst allows for different PV components systems to be modelled and provides an extensive database of modules and inverters available on the market.

Near Here: Table 3. Available Energy at Inverter Output.

A selection of $2 \mathrm{kWp}$ systems, for a Sheffield, UK weather location, with a $30^{\circ}$ angle and South azimuth, were modelled in PVSyst - to match the size of the system modelled in 
SAP, to determine if PV components had any effect on SAP rating. Three combinations of PV Panels / Inverters were modelled in PVSyst; each with a peak power of $2 \mathrm{~kW}$. An array of $40 * 50 \mathrm{Wp}$ Sulfurcell SGC50 HV-F panels was modelled with a SMA Sunny Boy 2100GT inverter. This was compared with an array of $10 * 200 \mathrm{Wp}$ Kyocera GHT200 panels modelled with a SMA Sunny Boy $2100 \mathrm{GT}$ inverter. The final test case was an array of 10 * Eurener PEPV 200 panels with a Suntechnics STW1900. Table 3 indicates the variability of available energy (kWh/year). Table 3 also shows that different selections of PV panel and inverter can lead to a variation of the PV output of approximately $+/-10 \%$ without altering any of the assumptions. The variation in PV output can account for an adjustment to the SAP rating of $+/-1$.

SAP results are consistent with PVSyst for a typically installed $2 \mathrm{~kW}$ PV system in the UK.

\section{Effect of Weather Location}

A typical PV system was then modelled in PVSyst for different UK locations, to determine the effect on SAP ratings. The location of Sheffield was selected to match the location of SAP. Efford was selected as a reference point for the south of England. Eskdalemuir was selected as a reference weather location for Southern Scotland.

Figure 2. Weather Locations utilised in detailed simulation

The three weather data files used in PVSyst were generated by Meteonorm (Meteotest, 2009) to ensure consistency. The two additional weather stations were selected because of the 
availability of measured solar radiation, which improves the quality of Meteonorm-generated weather data files.

Table 4 details available energy at Inverter Output in kWh/year: the Eskdalemuir location shows a reduction of over $187 \mathrm{kWh} /$ year as calculated by PVSyst $(-11 \%)$, which would be equivalent to a SAP rating of B 80 . The Efford location highlights an improvement of $316 \mathrm{kWh} /$ year over SAP $(+19 \%)$, resulting in a SAP rating of B 83. SAP can be used to rank energy saving investments and a small difference of one or two points in SAP ratings could in fact be significant. In this respect, it could be argued that PV systems do not get the credit they deserve in some locations (e.g. South England) while their savings are overestimated for other locations (e.g. North Scotland).

Table 4. Results for several location based upon $2 \mathrm{kWp}$ South Facing PV System at $30^{\circ}$.

\section{Combined effect of PV systems and Weather data}

A combination of varying PV systems and UK Weather locations were modelled in PVSyst to establish the effect that this combination would have on $\mathrm{kWh} /$ year and SAP rating. The Sulfurcell SGC50 HV-F panels efficiency per module area of 6.41\%) are an example of CIS thin film technology. An area of $33 \mathrm{~m}^{2}$ would be required to include a $2 \mathrm{kWp}$ array would be required if this was to be implemented. The Eurener PEPV 200 (efficiency per module area of 11.64\%) and Kyocera GHT200 panels (efficiency per module area of 14.2\%) are examples of a Single crystalline PV, $17 \mathrm{~m}^{2}$ and $14 \mathrm{~m}^{2}$ would be required to install these $2 \mathrm{kWp}$ systems. The nominal rating of each PV system was provided by manufacturer supplied data via PVSyst, which is the rating power of each module at standard operating conditions. These 
conditions stipulate an irradiation of $1000 \mathrm{kWh} / \mathrm{m} 2$ with a module temperature of $25 \mathrm{C}$ (PVSyst, 2010).

Table 5 highlights that, in comparison to SAP calculated figure of $1667 \mathrm{kWh} / \mathrm{year}$ and rating of $\mathrm{B} 81,+33 \% \mathrm{kWh} /$ year and $+3 \mathrm{SAP}$ points variation can be demonstrated from the $2 \mathrm{kWp}$ Sulfurcell system installed in Efford. The $2 \mathrm{kWp}$ Eurener system modelled in Eskdalemuir highlights a $-18 \% \mathrm{kWh} /$ year and $-1 \mathrm{SAP}$ point variation.

Table 5. Results for several locations and components based upon $2 \mathrm{kWp}$ South Facing PV System at $30^{\circ}$.

\section{Other differences between SAP and PVSyst}

Results for a slope of $30^{\circ}$ and an azimuth of due south have been discussed so far. Other calculations were performed for different slopes and azimuths, combining different locations and different system components.

Table 6 details the comparison between $\mathrm{kWh} /$ year output from PVSyst and SAP based upon a combination of varying PV slopes and azimuths. A $2 \mathrm{kWp}$ system was simulated in PVSyst based upon a SMA Sunny Boy $2100 \mathrm{TL} 2.0 \mathrm{~kW}$ inverter and 10 Kyocera KC 200GHT-2 Polycrystalline $200 \mathrm{Wp}$ PV modules. The PV system modelled in SAP remained at $2 \mathrm{kWp}$ and matched the PV slopes and azimuths used in PVSyst, to allow for a comparison to be made.

Table 6. Results for several slopes and azimuths based upon a $2 \mathrm{kWp}$ PV System in a Sheffield, UK location. 
The differences calculated between SAP values for different orientations are generally within $10 \%$ of the differences calculated by PVSyst for the same orientations. SAP neglects the impact of incidence angle and seems to overestimate the performance for unfavourable orientations, such as Vertical North where the difference between PVSyst and SAP kWh/year yields was found to be $23 \%$. SAP results were always higher than PVSyst bar $60^{\circ}$ South where results from PVSyst and SAP were identical. A possible improvement to SAP would be to add a table detailing solar radiation that is corrected for the incidence angle effects. An example of information which could be detailed is the radiation transmitted through a single glazing instead of the incident radiation - this value would be useful for transmission through windows, glazed solar thermal collectors and PV.

\section{SDHW SIMULATION}

A typically installed SDHW system in the UK was taken to be a Glazed Flat Panel with an aperture area of $5 \mathrm{~m}^{2}$ (Energy Saving Trust, 2009), South facing, with a 300 litre dual coil domestic hot water cylinder. SAP requires Aperture Area, Collector Type (Evacuated Tube, Flat Panel or Unglazed), Collector Efficiency (zero-loss collector efficiency and linear heat loss coefficient of collector, $\mathrm{W} / \mathrm{m}^{2} \mathrm{~K}$ ), Roof Orientation, Pitch and shading. The SAP calculation to obtain the solar input is detailed below.

\section{SAP v9.82 calculation to determine contribution to domestic hot water}

$\mathrm{Q}_{\mathrm{s}}=\mathrm{S} * \mathrm{Z}_{\text {panel }} * \mathrm{~A}_{\mathrm{ap}} * \eta_{0} * \mathrm{UF} * \mathrm{f}\left(\mathrm{a}_{1} / \eta_{0}\right) * \mathrm{f}\left(\mathrm{V}_{\text {eff }} / \mathrm{V}_{\mathrm{d}}\right)$

Where:

$\mathrm{Q}_{\mathrm{s}} \quad=$ solar input, $\mathrm{kWh} /$ year 
$\mathrm{S}=$ total solar radiation on collector, $\mathrm{kWh} / \mathrm{m}^{2} /$ year (from SAP Table $\mathrm{H} 2$ )

$\mathrm{Z}_{\mathrm{panel}} \quad=$ shading factor for the solar panel

$\mathrm{A}_{\text {ap }} \quad=$ aperture area of collector, $\mathrm{m}^{2}$

$\eta_{0} \quad=$ zero-loss collector efficiency (from certified performance test or SAP default values)

$\mathrm{UF} \quad=$ utilisation factor

$\mathrm{a}_{1}=$ linear heat loss coefficient of collector, $\mathrm{W} / \mathrm{m}^{2} \mathrm{~K}$ (from certified performance test or SAP default values)

$\mathrm{f}\left(\mathrm{a}_{1} / \eta_{0}\right)=$ collector performance factor $=0.87-0.034\left(\mathrm{a}_{1} / \eta_{0}\right)+0.0006\left(\mathrm{a}_{1} / \eta_{0}\right)^{2}$

Veff $=$ effective solar volume, litres

$\mathrm{Vd} \quad=$ daily hot water demand, litres (from SAP tabulated data versus floor area)

$\mathrm{f}\left(\mathrm{V}_{\text {eff }} / \mathrm{V}_{\mathrm{d}}\right)=$ solar storage volume factor $=1.0+0.2 \ln \left(\mathrm{V}_{\mathrm{eff}} / \mathrm{V}_{\mathrm{d}}\right)$

subject to $\mathrm{f}\left(\mathrm{V}_{\text {eff }} / \mathrm{V}_{\mathrm{d}}\right)<=1.0$

Qs details a dwelling's kWh usage saved due to the installation of a SDHW system. The required auxiliary energy is then calculated taking into account the hot water energy required and distribution losses and tank losses. This auxiliary energy is then used in the main SAP worksheet where it is combined with the energy used for space heating, etc. to obtain the SAP rating. SAP also adds a fixed amount of $75 \mathrm{kWh} / \mathrm{y}$ to the electricity usage of a house to account for the energy required by the solar thermal circulating pump.

For our Standard Test Case dwelling with the typical SDHW system described above, SAP provides default efficiency values for solar collectors in Table H1 (see Table 7). It can be noted that the default efficiency for glazed collectors (flat-plate and evacuated tube) is significantly lower than values recommended by the IEA-SHC programme based on collector 
tests (IEA-SHC, 2004). The first-order heat loss coefficient $\left(a_{1}\right)$ in Table 7 is more than double of typical IEA values, so that the efficiency of evacuated tube collectors under nominal operations specified in the same IEA document is 0.76 for the IEA typical, and 0.6 for the SAP default. This is detailed in Table 7.

SAP designers have deliberately designed the default figures for efficiency of glazed collectors to be lower than some collector efficiencies such as those noted from the IEA-SHC program. SAP allows the user to enter the efficiency of specific collector base upon manufacturer supplied data, and therefore deliberately provides a low collector efficiency to encourage the use of real data in SAP.

Table 7. SAP Table H1 - Default Collector Parameters (IEA - SHC Figures in Brackets).

In SAP, hot water energy requirements are directly related to the total floor area (TFA) of a dwelling. The TFA of the STC dwelling is $104 \mathrm{~m}^{2}$. SAP Table 1 (Hot Water Energy Requirements) states that a dwelling with a $104 \mathrm{~m}^{2}$ TFA would have a hot water usage of 119 litres per day, with an Energy Content of Heated Water (including distribution losses) of $2532 \mathrm{kWh} /$ year. One key parameter is the loss coefficient of the hot water storage tank. In this study, it was assumed that the storage tank is at the upper limit of band " $\mathrm{B}$ " in standard EN 15332, i.e. $2.49 \mathrm{kWh}$ per $24 \mathrm{~h}$ for a 300 litre tank. SAP-calculated output of the auxiliary water heater is $3450 \mathrm{kWh}$ without a solar system, and $1929 \mathrm{kWh}$ with the system described above (assuming the same 300 litre storage tank is used in both cases). The calculated solar input is $1186 \mathrm{kWh}$ and the losses in the 300 litre tank drop from $559 \mathrm{kWh} / \mathrm{y}$ to $224 \mathrm{kWh} / \mathrm{y}$. The SAP rating for the STC dwelling increases from C 72 to C 74 . 


\section{Use of TRNSYS to determine $\mathrm{kWh} / \mathrm{year}$}

TRNSYS allows the detailed modelling of a solar thermal system. An identical Flat Plate Collector system to that modelled in the STC was modelled in TRNSYS, using standard components from the TESS libraries (TESS, 2007). The TRNSYS simulation was setup to represent a typical good practice system. The flow rate is set to $50 \mathrm{l} / \mathrm{h} \cdot \mathrm{m}^{2}$ with a $25 \mathrm{~W}$ pump, solar primary piping losses are set to $0.2 \mathrm{~W} / \mathrm{m} \cdot \mathrm{K}$. The domestic hot water profile is set to three draw-offs per day at $7 \mathrm{am}, 12 \mathrm{pm}$ and $5 \mathrm{pm}$, with respectively $40 \%, 20 \%$ and $40 \%$ of the daily volume. The tank loss coefficient was set to the same value as in SAP, i.e. $2.49 \mathrm{kWh}$ per $24 \mathrm{~h}$. The loss coefficient in EN 15332 is calculated for standardised temperatures (room $=20^{\circ} \mathrm{C}$, hot water $=65^{\circ} \mathrm{C}$ ) and SAP applies a "temperature factor" of 0.6 to this loss coefficient to allow for the tank not being continuously maintained at $60^{\circ} \mathrm{C}$. This would result in a very large discrepancy between SAP storage losses and TRNSYS storage losses if a hot water temperature of $60{ }^{\circ} \mathrm{C}$ was assumed. The TRNSYS simulation therefore assumes a hot water setpoint of $50{ }^{\circ} \mathrm{C}$ with a thermostatic valve bringing it down to $45^{\circ} \mathrm{C}$, and the daily load is adapted $\left(170\right.$ litres per day at $\left.45^{\circ} \mathrm{C}\right)$. The mains water temperature is $10{ }^{\circ} \mathrm{C}$ in average and varies by $+/-2.6^{\circ} \mathrm{C}$ over the year. SAP and TRNSYS results are presented in Table 8 .

Table 8. Results Overview.

TRNSYS results for the typical system described above, using SAP default efficiency parameters $\left(\eta 0=0.75\right.$ and $\left.\mathrm{a}_{1}=6 \mathrm{~W} / \mathrm{m}^{2} \mathrm{~K}\right)$, show a solar input of $1461 \mathrm{kWh} / \mathrm{y}$ and a value of $1782 \mathrm{kWh}$ for the water heater output. It is interesting to note that the solar input is $23 \%$ higher than the SAP value but the water heater output is only $7 \%$ lower. This is partly due to the different tank losses $(357 \mathrm{kWh} /$ year, i.e. $63 \%$ higher than the SAP value of 224 
$\mathrm{kWh} /$ year). The tank losses from TRNSYS are for the entire tank whereas SAP only directly counts losses from the main store section of a combined cylinder tank. The losses from the solar store section are not included in the SAP tank losses figure and are dealt with in SAP in the collector performance factor $\left(\mathrm{f}\left(\mathrm{a}_{1} / \eta 0\right)\right)$. Therefore a further evaluation of tank losses could be made between $214 \mathrm{kWh}$ (TRNSYS), based upon $357 \mathrm{kWh} /$ (300 litres / 180 litres), in comparison between the SAP losses of $224 \mathrm{kWh} / \mathrm{year}$. TRNSYS results for tank losses are therefore within $4 \%$ of SAP tank losses.

As described above for the PV simulations, it is possible to calculate the SAP rating obtained if the SDHW system was simulated in TRNSYS and that result utilised in the main SAP calculation. The water heater output calculated in TRNSYS is then used rather than the solar input, so that the different tank losses are taken into account. For the system described above, the SAP rating is unchanged at $\mathrm{C} 74$.

\section{Effect of Collector parameters}

SAP calculations and TRNSYS simulations were performed for collectors with parameters matching the typical values recommended by IEA (IEA-SHC, 2004). For glazed flat-plate collectors, the TRNSYS solar input is $32 \%$ higher than the SAP value, while the water heater output is $13 \%$ lower. For IEA typical evacuated tube collectors, TRNSYS predicts a $47 \%$ higher solar input and 23\% lower water heater output. For both IEA typical collectors, the SAP rating increases from $\mathrm{C} 74$ to $\mathrm{C} 75$ if TRNSYS results are utilised in the SAP calculation.

Another interesting comparison is between a SAP calculation using the default SAP efficiency for evacuated tubes and a TRNSYS simulation using default IEA parameters for 
evacuated tubes. The latter gives a solar input $81 \%$ higher and a water heater output 35\% lower than SAP calculations with default parameters for evacuated tubes. The SAP rating would be $\mathrm{C} 75$ instead of $\mathrm{C} 74$. This underlines the importance of using certified performance data in SAP rather than default values, which have been designed to always be lower than typical figures.

\section{Effect of SDHW Weather Location}

TRNSYS was used to simulate an identical system (system described above with typical IEA flat-plate performance) for a number of UK weather locations. Figures were calculated for a northerly and southerly location in the UK, as in the PV section.

The TRNSYS calculated values for solar input are 17\% higher in Eskdalemuir and $60 \%$ higher in Efford, with a water heater output respectively $4 \%$ lower and $31 \%$ lower. The equivalent SAP rating would increase from C 74 to C 75 in Sheffield and Efford but remain at C 74 for the Eskdalemuir location. Weather location can therefore play a highly significant factor in determining the output of SHDW (and PV) systems, which are at present not taken into account by SAP due to its use of one weather location for the UK.

\section{Other differences between SAP and TRNSYS}

Simulations were performed for different slope and azimuth angles, different locations and different collector parameters. A selection of these results is shown in Table 8. The most striking differences appear for high performance collectors such as the IEA-typical evacuated 
tubes, for which differences in solar input reach $+72 \%$ (in Efford) and differences in water heater output reach $-39 \%$, leading to a different SAP rating (C 75).

Another interesting conclusion from these results is that the influence of the collector slope is different in SAP and TRNSYS. Systems with a higher slope than $30^{\circ}$ always perform worse in SAP, while the optimum slope in TRNSYS is $45^{\circ}$ for maximum solar input and $60^{\circ}$ for minimum water heater output. A higher tilt angle will increase the performance of SDHW systems in winter while the performance in summer will be affected less, especially for systems with a high solar fraction. This increases the match between supply and demand, and is not taken into account in SAP. For Sheffield, the difference in solar input between TRNSYS and SAP moves from $47 \%$ to $59 \%$ for IEA evacuated tubes when the slope goes from $30^{\circ}$ to $60^{\circ}$ (South-facing). Both systems have a rating of C74 in SAP and C75 when TRNSYS results are taken into account.

Finally, using a rated pump power of $25 \mathrm{~W}$ the TRNSYS-calculated pumping energy was between $50 \%$ and $75 \%$ of the SAP value (which is set to $75 \mathrm{kWh}$ in all configurations).

\section{BRE INNOVATION PARK CASE STUDY}

The BRE Innovation Park (based at BRE, Garston, UK) allows companies to construct homes of the future, demonstrating implementations of Renewables and Modern Methods of Construction.

\section{Stewart Milne Sigma Home}


A preliminary study of the Sigma Home was conducted. The Sigma Home has been designed in a similar fashion to a standard UK Victorian Dwelling built during the period 1837 to 1901, offering compact, adjustable living over 4 floors. The Sigma Home meets level 5 of the Code for Sustainable Homes (DCLG, 2006) which rates the sustainability performance of a dwelling on a scale of 1 to 6 . The dwelling has a total floor area of $116 \mathrm{~m}^{2}$ which can be compared with a typically sized a new detached 3 bed-roomed dwelling completed in the UK of $94 \mathrm{~m}^{2}$ (Scottish Government Social Research, 2009). The Sigma Home is equipped with PV and SDHW systems which will be modelled as part of this research. The Stewart Milne Sigma Home also has a Micro Wind Turbine installation, which is not considered here. A recent Post Occupancy Evaluation Research Programme has been concluded for the Sigma Home; this details that the Micro Wind Turbine installation underperformed and generated little effective electricity (Stewart Milne, 2009).

Figure 3. Stewart Milne Sigma Home BRE Innovation Park, Garston, UK.

Discussions with Stewart Milne and the project development company (RD Energy Solutions Ltd) who sourced the Renewables allowed for access to plans of the dwelling and installed Renewables. The SIGMA home was modelled with our best understanding of the data received (Lyle, 2009 and Dalgarno, 2009). One main simplification is that existing shading is ignored both in the SAP assessment and in the detailed modelling.

\section{SAP modelling of SIGMA Home}

As detailed in Table 9, the Sigma Home was modelled in SAP and produced a SAP Rating of C 73 disregarding all renewables. SAP suggested improvements were the addition of Solar Water Heating, Solar Photovoltaic (PV) Panels and a Wind Turbine. 
Table 9. Sigma Home SAP Input Listings.

\section{SIGMA Home + PV Modelled in SAP}

The installation of PV at the Stewart Milne Sigma House utilises Kyocera KC200GHT PV Panels. $4.8 \mathrm{kWp}$ are installed on an east facing low pitch $\left(10^{\circ}\right)$ and $1.2 \mathrm{kWp}$ are installed on the south facing vertical façade; with a Mastervolt QS6400 inverter (Lyle, 2009 and Dalgarno, 2009). The east facing PV pitch was taken as $0^{\circ}$ (i.e. horizontal) with no shading in SAP for the purposes of this preliminary study (PVSyst uses the correct pitch).

$4.8 \mathrm{kWp}$ of horizontal PV and $1.2 \mathrm{kWp}$ of vertical PVs have been inputted into SAP. The area of vertical PVs were adjusted in SAP to the equivalent $\mathrm{kWp}$ if they were $0^{\circ}$ using SAP Table H2 $(1.2 \times 724 / 933=0.93 \mathrm{kWp})$. In total, $5.73 \mathrm{kWp}$ of horizontal PVs were entered into SAP, with very little shading selected.

SAP Calculation to determine $\mathrm{kWh} / \mathrm{year}-\mathrm{PV}$

The SAP calculation to determine useful energy production of $\mathrm{PV}$, in $\mathrm{kWh} / \mathrm{year}$, was employed:

Electricity Produced by the PV Module $=0.80 * \mathrm{kWp} * \mathrm{~S} * \mathrm{Z}_{\mathrm{PV}}$

$5.73 \mathrm{kWp}$ of horizontal PV with no shading will generate $4278 \mathrm{kWh} /$ year $(0.80 * 5.73 * 933$

* 1.0). The effect of the installation of this PV array is to increase the SAP Rating to A 94, an increase of 21 SAP points 


\section{SIGMA Home PV modelled in PVSyst}

Matching the installation at the SIGMA home, a $4.8 \mathrm{kWp}$ east facing roof mounted array $\left(10^{\circ}\right.$ pitch) combined with a $1.2 \mathrm{kWp}$ vertical south facing array was modelled in PVSyst. To closely match the system installed at the Sigma Home, a Mastervolt SunMaster QS 6400 $5.2 \mathrm{~kW}$ inverter was selected with an array of 30 Kyocera KC200GHT-2 Polycrystalline $200 \mathrm{Wp}$ PV modules. 24 panels were modelled as being roof mounted with 6 panels modelled as a south facing façade array. When modelled in PVSyst, $3796 \mathrm{kWh} / \mathrm{year}$ is calculated for available energy at the inverter output. This is detailed in the PVSyst generated Sankey Diagram, detailing losses for the installed Sigma Home PV system.

Figure 4. Sankey Diagram detailing PV Production for Sigma Home.

This value is $12 \%$ lower than the SAP-calculated value $(4278 \mathrm{kWh} /$ year), which is consistent with the tendency of SAP to overestimate the performance of PV for non-optimal orientations. The SAP rating obtained by replacing the SAP-predicted PV output with the PVSyst value is A 93, i.e. a reduction of one SAP point.

\section{SIGMA Home + SDHW modelled in SAP}

The installation of SDHW at the Sigma Home utilises 4 SCHOTT EPC 16 Evacuated Tube SDHW collectors and 2 Schuco 200 L dual coil unvented cylinders. The solar collectors are on a pitched roof facing South, with a slope of $30^{\circ}$. In the absence of manufacturer data the thermal loss coefficient of each 200 litre tank was assumed to be at the higher end of " $\mathrm{B}$ " band in EN 15322, i.e. $1.94 \mathrm{kWh}$ per $24 \mathrm{~h}(3.88 \mathrm{kWh} /$ day for two tanks). Hot water usage per day was set to be 126.7 litres, as defined in SAP Table 1. 
Table 10. SAP Table 1.

SIGMA Home + SAP v9.82 calculation to determine contribution to domestic hot water

With SCHOTT ETC 16 Technical Information:

$\mathrm{Q}_{\mathrm{s}}=\mathrm{S} * \mathrm{Z}_{\text {panel }} * \mathrm{~A}_{\text {ap }} * \eta_{0} * \mathrm{UF} * \mathrm{f}\left(\mathrm{a}_{1} / \eta_{0}\right) * \mathrm{f}\left(\mathrm{V}_{\mathrm{eff}} / \mathrm{V}_{\mathrm{d}}\right)$

$\mathrm{Q}_{\mathrm{s}}=1042 * 1 * 3.232 * 0.773 * 0.646 * 0.823 * 1$

$\mathrm{Q}_{\mathrm{s}}=1384 \mathrm{kWh} /$ year

Based upon the technical information available for the Schott ETC 16 Evacuated Tube Collector (SCHOTT-Rohrglas GmbH, 2008), a zero loss collector efficiency, $\eta 0$, of 0.773 and a collector heat loss coefficient, $\mathrm{a}_{1}$, of 1.09 were utilised. A total aperture area of $3.232 \mathrm{~m} 2$ was selected in SAP based upon the Sigma Home specification of 4 Schott ETC 16 collectors, each with an aperture area of $0.808 \mathrm{~m} 2$.

The Solar Input, Qs, was calculated to be $1384 \mathrm{kWh} /$ year. This increased the SAP rating of the SIGMA Home from C 73 to C 78, an increase of 5 SAP points. 
The installation described above was modelled in TRNSYS. The calculated solar input is $1839 \mathrm{kWh}(25 \%$ above the SAP value of $1384 \mathrm{kWh} /$ year) and the water heater output is $1831 \mathrm{kWh}(8 \%$ under the SAP value) of $1998 \mathrm{kWh} /$ year.

TRNSYS derived tank loses for the SIGMA home SDHW system were 620kWh for the entire tank, sized at 400 litres. This cannot be compared directly with the SAP calculated tank losses of $321 \mathrm{kWh} / \mathrm{year}$ for the SIGMA Home, as this is based upon a tank sized at 160 litres. In considering a combined tank SAP only directly considers losses from the section of the tank which is controlled by the boiler. The losses from the solar store section of the combined tank are stored in the SAP collector performance factor $\left(\mathrm{f}\left(\mathrm{a}_{1} / \eta 0\right)\right)$. Therefore, for a direct comparison of losses the TRNSYS losses for the SIGMA home tank should be 248 $\mathrm{kWh} /$ year based upon $620 \mathrm{kWh} /$ (400litres / 160litres). Based upon a combined tank the losses from TRNSYS for the non solar portion of the tank is therefore $23 \%$ lower than those recorded in SAP (248 kWh vs. $321 \mathrm{kWh}$ ). For a system with a separate solar cylinder, the SAP tank losses would be $801 \mathrm{kWh} /$ year.

The SAP rating obtained by using the TRNSYS-calculated water heater output in SAP is unchanged at $\mathrm{C} 78$ (the actual value increases from 77.74 to 78.45 , both of which round to $78)$.

SIGMA Home + SDHW + PV modelled in SAP

With the previously described PV and SDHW modelled together in SAP, the calculated SAP Rating is A 99.

If the results of PVSyst and TRNSYS are used in the main SAP procedure, the calculated rating is unchanged at A 99 (it actually decreases from 99.39 to 98.64 , both round 
to 99). The PV output is adjusted downwards and the solar thermal input is adjusted upwards, resulting in a small downwards adjustment overall.

A good agreement is therefore seen between the SAP results and the combination of SAP results with the addition of detailed modelling results.

\section{CONCLUSIONS}

The importance of accuracy within the methodology employed to measure the energy performance of dwellings has been highlighted by legislation such as the Energy Performance of Buildings Directive. The study utilised SAP as an exemplar for simplified dwelling assessment methodologies whilst highlighting other countries procedures and also countries which have adopted the SAP framework. This clarifies that the research presented here is applicable to not only the UK and to SAP but to countries throughout the world that employ simplified dwelling assessment methodologies, especially those with comparable levels of solar radiation. The comparisons between SAP 2005 v9.82 and PVSyst simulations show a very good agreement for the base case photovoltaic system $\left(30^{\circ}\right.$ slope, facing south, standard system components, and Sheffield weather data). The difference in energy output at the inverter is $2 \%$. SAP only uses the rated nominal power of the PV array in the calculation and assumes a central weather location. Detailed PVSyst simulations show that using different system components (e.g. thin film versus mono-crystalline cells) can lead to differences of $+/-10 \%$ in output. This leads to a difference of $+/-1$ in the SAP rating if the PV output calculated by PVSyst is used in the SAP assessment. Further research of the PV Panels compared in this study highlighted the differences which can be found between the nominal power and Peak Maximum Power Point $\left(\mathrm{P}_{\mathrm{MPP}}\right)$ of a selected Panel. For example, the nominal 
power of the Sulfurcell SCG 50-HV-F was recorded by PVSyst as 50Wp, with a $\mathrm{P}_{\mathrm{MPP}}$ of $52.8 \mathrm{~W}-5 \%$ higher than the nominal power. Conversely, the Eurener PEPV 200 is recorded as a $200 \mathrm{Wp}$ nominal power panel but the $\mathrm{P}_{\mathrm{MPP}}$ is $2.6 \%$ lower at $194.8 \mathrm{~W}$. These differences between nominal power and $\mathrm{P}_{\mathrm{MPP}}$ are currently not taken into account in simplified assessments such as SAP.

Simulations were performed using weather data recorded at one station representative of Southern Scotland, and one station representative of Southern England. This leads to differences within $[-11 \% /+19 \%]$ PV output and $[-1 /+2]$ in equivalent SAP rating. By combining the impact of different weather locations and different system components, PVSyst shows differences within $[-18 \% /+33 \%]$ in PV output and $[-1 /+3]$ in equivalent SAP rating. Results for different slopes and azimuth angles also show that SAP seems to systematically overestimate the performance of PV systems for unfavourable orientations (e.g. vertical North facing), and slightly underestimate the performance for more favourable orientations (e.g. $60^{\circ}$ facing South). This is probably explained by the fact that SAP does not take into account the impact of incidence angle.

SAP assessment of solar thermal domestic hot water systems (SDHW) was compared to detailed TRNSYS simulations. TRNSYS results for a standard system using SAP default parameters for collector efficiency show a solar input which is $23 \%$ higher than SAP results, but the tank losses are also larger for the entire tank (but lower when compared against the SAP calculated tank losses for the non solar store section of the tank) which results in the water heater output to be only $7 \%$ lower. The SAP default parameters for collector efficiency are significantly lower than typical values published by the IEA. Results show that using SAP default parameters instead of IEA default parameters leads to under-predicting the savings at the water heater output by $35 \%$. This highlights the importance of using manufacturer 
supplied data in SAP. If certified parameters are available, they can be used in SAP, and comparisons using the same efficiency parameters in TRNSYS and SAP shows that the differences increase for higher performance collectors. Using IEA typical Evacuated Tube data, TRNSYS predicts a higher solar input $(+47 \%)$, a lower water heater output $(-23 \%)$ and an improved SAP rating (C75 vs. C74).

As for the PV, SAP assumes one location representative of the whole UK. Using weather data for Southern England (Efford), leads to differences of up to $60 \%$ in solar input and up to $31 \%$ in water heater output. The SAP rating obtained by utilising these values in the SAP procedure leads to an improved rating: (C 75 vs. C 74). The results also show that SAP seems to underestimate the performance of SDHW systems when the slope is increased, as it ignores the impact of a better match between supply and demand when available radiation is increased in winter and reduced in summer. SAP seems to use a conservative estimate for the energy required for water pumping, which is set to $75 \mathrm{kWh}$ for all systems. TRNSYS simulations using a typical pump rated power $(25 \mathrm{~W})$ show that the energy use is between $50 \%$ and $75 \%$ of the SAP value.

\section{DISCUSSION}

This study has shown a good agreement between SAP results and detailed simulations for PV and a reasonable agreement for SDHW systems, when the most typical system configurations are used. It was highlighted that SAP is restrictive as specific values for PV panels, inverters and SDHW systems cannot be entered. Detailed simulation programs can be time consuming to input and calculate results, and more prone to user input error. As SAP relies upon a series of simple equations, there is less scope for errors to occur in calculations. This contrasts with 
detailed analysis tools such as TRNSYS and, to a lesser extent, PVSyst. These software programs offer a greater degree of detail to be modelled, but the learning curve required to use them is as high as the opportunity to make errors inputting data or selecting components and system configurations. Therefore simplified methodologies such as SAP must focus on the most important variables and factors utilised in dynamic simulation to ensure accurate results, whilst keeping inputs to a minimum to ensure speed and ease of use. This study has highlighted that this can be a difficult balance to achieve.

For the calculation of PV data it was found that detailed simulation tools such as PVSyst record and differentiate between the recorded nominal power and PMPP, and in some cases there can be a discrepancy here. This discrepancy is apparent in SAP results as only the nominal rating of a PV panel is recorded and used for results calculation. This can cause some error in results as, for example, a $200 \mathrm{~W}$ nominal power PV panel can have a PMPP which is $+/-5 \%$ this figure. SAP does not record this difference and so all panels of a nominal rating are recorded identically in SAP. Analysis of the major factors which can affect the calculated $\mathrm{kWh} /$ year for PV determined that the inverter used to convert from DC to AC could have a dramatic effect on energy available from a PV system (Salas and Olias, 2009).

The hot water draw off profile cannot be altered in SAP and this emphasises that the figures produced by SAP are representative only. This is a major difference between SAP and TRNSYS; TRNSYS results are specific to each particular case with exact details simulated and are not designed to be representative across a range of cases. Tank losses were found to be an area where SAP and TRNSYS compared poorly. A major factor in this was that SAP was found to ignore losses from the solar store section of a tank and deal with these 
in the collector performance factor $\left(f\left(a_{1} / \eta 0\right)\right)$. The collector performance factor has a similar purpose to the 0.8 factor in the SAP PV calculation - many factors which a dynamic simulation tool such as TRNSYS would record independently are accounted for by one simplified figure. The collector performance factor also underlines that SAP does not allow for the recording of an $a_{2}$ term (the second-order loss coefficient), corresponding to $a_{1}$.

Our findings illustrate that SAP seems to systematically overestimate the performance of PV and SDHW systems for unfavourable orientations and that this could be caused by the impact of incidence angle not being taken into account in SAP. An additional SAP table detailing Transmitted Solar Radiation could be added to the SAP Methodology to improve SAP in this area. The centralised weather location of Sheffield utilised by SAP allows for homes throughout the UK to be compared directly. However, this has the effect of overestimating PV and SDHW output in northerly areas of the UK whilst underestimating output in southerly areas of the UK. Different system configurations and weather data locations were simulated and showed significant differences in performance, up to $35 \%$. This seems to be even more the case for SDHW systems with high efficiency collectors; further work is required in this area. SAP ratings are typically affected by differences smaller than 1 , but in some cases differences of 3 have been noted. As simplified methodologies such as SAP are sometimes used to rank energy saving measures, these differences can be significant.

Simplified assessment methodologies such as SAP and detailed tools such as PVSyst or TRNSYS all play a role in reducing the environmental impact of the built environment, and the authors do not believe that rating systems should be based on detailed simulation results - it would not be practical and would probably be counterproductive to add a lot of complexity to standard assessment tools. Keeping this in mind, our work has shown that 
some of the discrepancies between SAP and detailed results could be resolved by increasing SAP's modelling resolution in the following respects:

- Considering different weather locations would allow renewable energy technologies to be ranked more fairly, as illustrated by the differences between results in Efford and Eskdalemuir

- $\quad$ For PV systems, including the Incidence Angle Modifier effects into incident radiation tables would give a fairer representation of non-optimal PV array orientations

For SDHW systems, increasing the time resolution of the modelling equation (e.g. from yearly to monthly) would allow to account for the (mis)match between solar heat availability and demand. This would allow a better assessment of systems with a lower or higher solar fraction than the typical one.

\section{FURTHER WORK}

As stated in the discussion section, further research is required to clarify the differences that have been identified between the calculated PV and SDHW output from detailed simulation tools, such as PVSyst and TRNSYS, and the results from simplified methods such as SAP. Precise further work will further identify the reasons for these differences. Specifically this will clarify what additional variables, or modification of current SAP variables, would result in simplified outputs which are more consistent with the detailed counterparts.

Further work is required to state if simplified methodologies such as SAP should explicitly or implicitly record the performance of a PV Inverter, based upon the European Efficiency of Inverters. The European Efficiency of Inverters has been in use throughout Europe since 1991 and is the function of the efficiency of an inverter at defined percentage 
values of nominal AC power (Valentini et al, 2008). Further work should also focus on the difference between Nominal Rated Power and Peak Maximum Power Point (PMPP) of a PV Panel. This will clarify the variation this can cause with calculated PV output and if simplified assessments such as SAP should be updated to allow the recording of PMPP of panels. Supplementary research related to the effect of an Incidence Angle Modifier (IAM) (Nilsson, Brogren et al. 2006) and Maximum Power Point Tracker (MPPT) (Enrique, Andújar et al. 2009), and how simplified methodologies such as SAP take this into account is also required.

The impact of Solar Incident Angle Modifier to a SDHW calculated output should also be further researched. Specific work is required to confirm the impact of this upon the output of evacuated tube collectors. Further work should investigate the performance of SDHW systems in more detail: impact of design parameters (e.g. set-point temperature, tank volume and losses), and draw-off profile. The systematic differences noted in this study (ignoring the incidence angle impact for PV and the supply-demand match and solar radiation utilisation for SDHW) will also be investigated in detail with the view to suggest improvements to the SAP methodology. Further study will confirm if SAP should take into account the second-order loss coefficient in addition to the $\mathrm{a}_{1}$ coefficient. Additional focus on tank losses and the SAP SDHW Utilisation Factor and Collector Performance Factor would also be beneficial. The impact of shading for SDHW and PV systems and how SAP can best take this factor into account should also be assessed. It is well known that shading can have a devastating effect on PV performance, and it is unclear how the basic categories in SAP can address this. 
Comparisons between SAP and other comparable simplified methodologies (such as others used to meet other European nations EPBD obligations) would highlight if the issues raised from this research are common for other simplified assessment methodologies. A comparative assessment between different simplified methodologies and SAP is important future work to benchmark SAP against similar comparable methodologies.

\section{ACKNOWLEDGEMENTS}

The authors would like to thank the BRE Trust for the funding and continued assistance of this research.

Stewart Dalgarno, Director of Product Development, Stewart Milne Group and Andrew Lyle, Director, Renewable Devices Energy Solutions Ltd., were both helpful in providing details for the Sigma Home. 


\section{REFERENCES}

Anderson, B. R., Chapman P. F., Cutland N. G., Dickson C. M., Doran S. M., Henderson G., Henderson J. H., Iles P. J., Kosmina L., and Shorrock L. D. 2001. BREDEM-8 Model Description, BRE

Anderson, B. R., Chapman P. F., Cutland N. G., Dickson C. Henderson G., Henderson J. H., Iles P. J., Kosmina L., and Shorrock L. D. 2001. BREDEM-12 Model Description, BRE

Bahij A. S., James P. A. B. 2006. Urban Energy Generation: the added value of photovoltaics in social housing. Renewable and Sustainable Energy Reviews 11 (2007), pp2121 - 2136

British Standards. 2007. BS EN 15332:2007. BSI.

BRE, 2008. SAP 2005. The Government's Standard Assessment Procedure for Energy Rating of Dwellings. 2005 Edition, revision 2, BRE.

Cooper, G.A., 2008. SAP 2005 and Low Energy Dwellings. Oxford Brookes University, UK.

Dalgarno, S. 2009. Personal Communication. Stewart Milne Group.

Davidson, 2009. EPBD Energy Calculation Procedures - an overview. The CENSE Project Leading the CEN Standards on Energy performance of buildings to practice.

DIAG, 2010. The Building Performance Directive Implementation Advisory Group. Available from: www.diag.org.uk accessed 2010-01-23

DCLG, 2007. Building Regulations Energy efficiency requirements for new dwellings - A forward look at what standards may be in 2010 and 2013. Department for Communities and Local Government, London, UK

DCLG, 2006. Code for Sustainable Homes - A step-change in sustainable home building practice. Department for Communities and Local Government.

Deutsche Energie-Agentur, 2009. Energy Performance Certificate for Buildings Information about the activities of the German Energy Agency. Available from: www.zukunft-haus.info/en/energy-certificate.html accessed 2010-01-23

Duffy, M., Hiller, M., Bradley, D, Keilholz, W., Thornton, J.,2009. TRNSYS - Features and Functionality for Building Simulation 2009 Conference. Eleventh International IBPSA Conference, Glasgow, Scotland. pp1950-1954

Dyrbol and Aggerholm, 2008. Implementing the EPBD in Denmark. Available from www.epbd-ca.org accessed 2010-01-23

Energy Saving Trust, 2009 [online]. Generate your own Electricity; Solar Electricity. Available from: www.energysavingtrust.org.uk/Generate-your-own-energy accessed 2010-01-23

Enrique, J. M., J. M. Andújar, et al. "A reliable, fast and low cost maximum power point tracker for photovoltaic applications." Solar Energy 84(1): 79-89.

European Commission, 2006. Science for Environment Policy. DG Environment News Alert Service. Energy Rating Systems in Europe. European Commission DG ENV News Alert Issue 20.

GASTEC at CRE Ltd (GaC). 2010. SEDBUK - The Boiler Efficiency Database. Available from: www.sedbuk.com accessed 2010-01-23

Hens, H. 2007. Building Physics - Heat, Air and Moisture. Fundamentals and Engineering Methods with Examples and Exercises. Ernest \& Sohn.

IEA-PVPS, 2007. Trends in Photovoltaic Applications - Survey report of selected IEA countries between 1992 and 2007. Report IEA-PVPS T1-17:2008. International Energy Agency, Photovoltaic Power Systems Programme. St. Ursen, Switzerland 
IEA-SHC, 2004. Recommendation: Converting solar thermal collector area into installed capacity $\left(\mathrm{m}^{2}\right.$ to $\left.\mathrm{kWth}\right)$. International Energy Agency, Solar Heating and Cooling Programme. Available from www.iea-shc.org accessed 2010-01-23

Jarnagin, R. E., Colker, R. M., Nall, D., Davies, H., 2009. ASHRAE Buildings EQ. Program Will Help Owners, Operators Assess Buildings and Guide Good Descisions. Published in ASHRAE Journal December 2009. Available from www.buildingeq.com accessed 2010-01-23

Kummert, M., Bradley, D., McDowell, T., 2004. TRNSYS Validation - Using validation tool sin the development of TRNSYS 16. TRNSYS Users Day - Transsolar Stutgart March 26 2004. Available from: software.cstb.fraccessed 2010-01-23

Lausten, 2005. Energy Labelling of Buildings. Existing Experience with Certification of Buildings in Denmark; Danish Energy Authority. Presented to Engineers Ireland, Dublin, 29 $9^{\text {th }} \quad$ November $2005 . \quad$ Available from: ww.sei.ie/Your_Building/EPBD/Implementation of the EPBD in the EU accessed 2010-01-23

Lyle, A. 2009. Personal Communication. Renewable Devices Energy Solutions Ltd.

McWhinney, M., Fanara, A., Clark, R., Hershberg, C., Schmeltz, R., Roberson, J., ENERGY STAR product specification development framework: using data and analysis to make program decisions, Energy Policy, Volume 33, Issue 12, August 2005, Pages 16131625, ISSN 0301-4215, DOI: 10.1016/j.enpol.2004.02.001.

Meteotest 2010. Meteonorm - Global Meteorological Database version 6.1, Meteotest, Bern, Switzerland.

Míguez J.L. et al. (2006) "Review of the energy rating of dwellings in the European Union as a mechanism for sustainable energy", Renewable and Sustainable Energy Reviews 10: $24-45$

Murray, M., Finlayson, N., Kummert, M, Macbeth, J., 2009. Live Energy TRNSYS TRNSYS Simulation within Google Sketchup. Eleventh International IBPSA Conference, Glasgow, Scotland. pp1389-1396

Nilsson, J., M. Brogren, et al. (2006). "Biaxial model for the incidence angle dependence of the optical efficiency of photovoltaic systems with asymmetric reflectors." Solar Energy 80(9): 1199-1212.

Official Journal of the European Communities, 2003. Directive 2002/91/EC of the European Parliament and of the Council of 16 December 2002 on the energy performance of buildings. European Parliament.

PVSyst. 2010. Study of Photovoltaic Systems - V.4.33. University of Geneva, Switzerland.

Perers, B., Bales, C. 2002. A Solar Collector Model for TRNSYS Simulation and System Testing. IEA - Solar Heating and Cooling Programme.

Ren, M J., Cotton, M., Brown, K., Palmer, G. 2007. Meeting the current and future challenges for sustainable building designs - Case studies. Proc. 10th International Building Performance Simulation Conference and Exhibition, pp 1831-1838.

Salas, V., Olias, E. 2008. Overview of the state of technique for PV inverters used in low voltage grid-connected PV systems: Inverters below $10 \mathrm{~kW}$. Renewable and Sustainable Energy Reviews 13 (2009) 1541-1550

SAVE $N^{\circ}$ XVII/4.1031/Z/99-261, 2001. BELAS - Energy Labelling of Existing Buildings.

SCHOTT-Rohrglas GmbH, 2008. SCHOTT Evacuated Tube Collector ETC 16 Technical Data. Available from: www.schott.com accessed 2010-01-23

Schoen, T., Prasad, D., Ruoss, D., Eiffert, P.and Sørensen, H., 1998. Status report of Task 7 of the IEA PV Power Systems Program. Available from: www.iea-pvps.org accessed 2010-01-23 
Scottish Government Social Research, 2009. Modelling Greenhouse Gas Emissions from Scottish Housing: Final Report. The Scottish Government.

Schüle, 2009. Implementing the EPBD in Different Member States. Presented at the International BuildingEQ Symposium, Berlin. Available from: www.buildingeqonline.net/index.php?id=164 accessed 2010-01-23

Shorrock L D., Anderson B. 1995. A Guide to the Development of BREDEM. BRE Information Paper IP 4/95. BRE, Garston.

Sustainable Energy Ireland, 2008. Dwelling Assessment Procedure (DEAP) 2008 Edition, Version 3.0. Irish official method for calculating and rating the energy performance of dwellings. Sustainable Energy Ireland.

Stewart Milne Group. 2009. The Sigma Home - The future of low energy, carbon neutral homes.

Available from: www.stewartmilne.com/media/Image/brochure/sigma $\% 20 \mathrm{II} \% 20$ build $\% 20$ system $\% 20$ brochure.pdf accessed 2010-01-23

Syed, A M., Fung, A. S., Ugursal, V. I. 2007. Analysis of the Potential of Using Photovoltaic and Wind Turbine Energy Systems in the Canadian Residential Sector. Proc. 10th International Building Performance Simulation Conference and Exhibition, pp 665-672.

TESS, 2007. TRNSYS Type 604, multi-node pipe model. Personal communication. Thermal Energy Systems Specialists, Madison, WI.

TRNSYS. 2010. TRNSYS 16. Thermal Energy System Specialists, LLC. Madison, Wisconsin.

Valentini, M., Raducu, A., Sera, D., Teodorescu, R. 2008. PV Inverter Test Setup for European Efficiency, Static and Dynamic MPPT Efficiency Evaluation. Optimization of Electrical and Electronic Equipment, 2008. OPTIM 2008. 11th International Conference on 22-24 May 2008 Page(s):433 - 438

Weiss, W., I. Bergmann and G. Faninger, 2008. Solar Heat Worldwide - Market and Contributions to the Energy Supply 2006 - Edition 2008. IEA, Solar Heating and Cooling Programme. AAE Intec, Gleisdorf, Austria.

Wittchen K. B., 2003. Building Integrated Photovoltaics in a Thermal Building Simulation Tool, Proc. 8h International Building Performance Simulation Conference and Exhibition, pp 1417-1422. 


\section{Nomenclature}

SAP PV

$0.80=\quad$ SAP empirical factor for PV

$\mathrm{S} \quad=\quad$ Annual solar radiation

$\mathrm{Z}_{\mathrm{PV}}=$ Shading factor

\section{SAP Solar Domestic Hot Water}

$\mathrm{Q}_{\mathrm{s}} \quad=\quad$ solar input, $\mathrm{kWh} /$ year

$\mathrm{S}=$ total solar radiation on collector, $\mathrm{kWh} / \mathrm{m}^{2} /$ year (from SAP Table H2)

$\mathrm{Z}_{\text {panel }}=$ Shading factor for the solar panel

$\mathrm{A}_{\mathrm{ap}} \quad=\quad$ aperture area of collector, $\mathrm{m}^{2}$

$\eta_{0}=$ zero-loss collector efficiency (from certified performance test or SAP default values)

UF $\quad=\quad$ utilisation factor

$\mathrm{a}_{1}=\quad$ linear heat loss coefficient of collector, $\mathrm{W} / \mathrm{m}^{2} \mathrm{~K}$ (from certified performance test or SAP default values)

$\mathrm{f}\left(\mathrm{a}_{1} / \eta_{0}\right)=\quad$ collector performance factor $=0.87-0.034\left(\mathrm{a}_{1} / \eta_{0}\right)+0.0006\left(\mathrm{a}_{1} / \eta_{0}\right)^{2}$

Veff $=$ effective solar volume, litres

$\mathrm{Vd}=$ daily hot water demand, litres

(from SAP tabulated data versus floor area)

$\mathrm{f}\left(\mathrm{V}_{\text {eff }} / \mathrm{V}_{\mathrm{d}}\right)=\quad$ solar storage volume factor $=1.0+0.2 \ln \left(\mathrm{V}_{\mathrm{eff}} / \mathrm{V}_{\mathrm{d}}\right)$

subject to $\mathrm{f}\left(\mathrm{V}_{\text {eff }} / \mathrm{V}_{\mathrm{d}}\right)<=1.0$

SAP Terminology

$\mathrm{TFA}=$ Total Floor Area 


\section{Environmental Impact $\left(\mathrm{CO}_{2}\right)$ Rating}

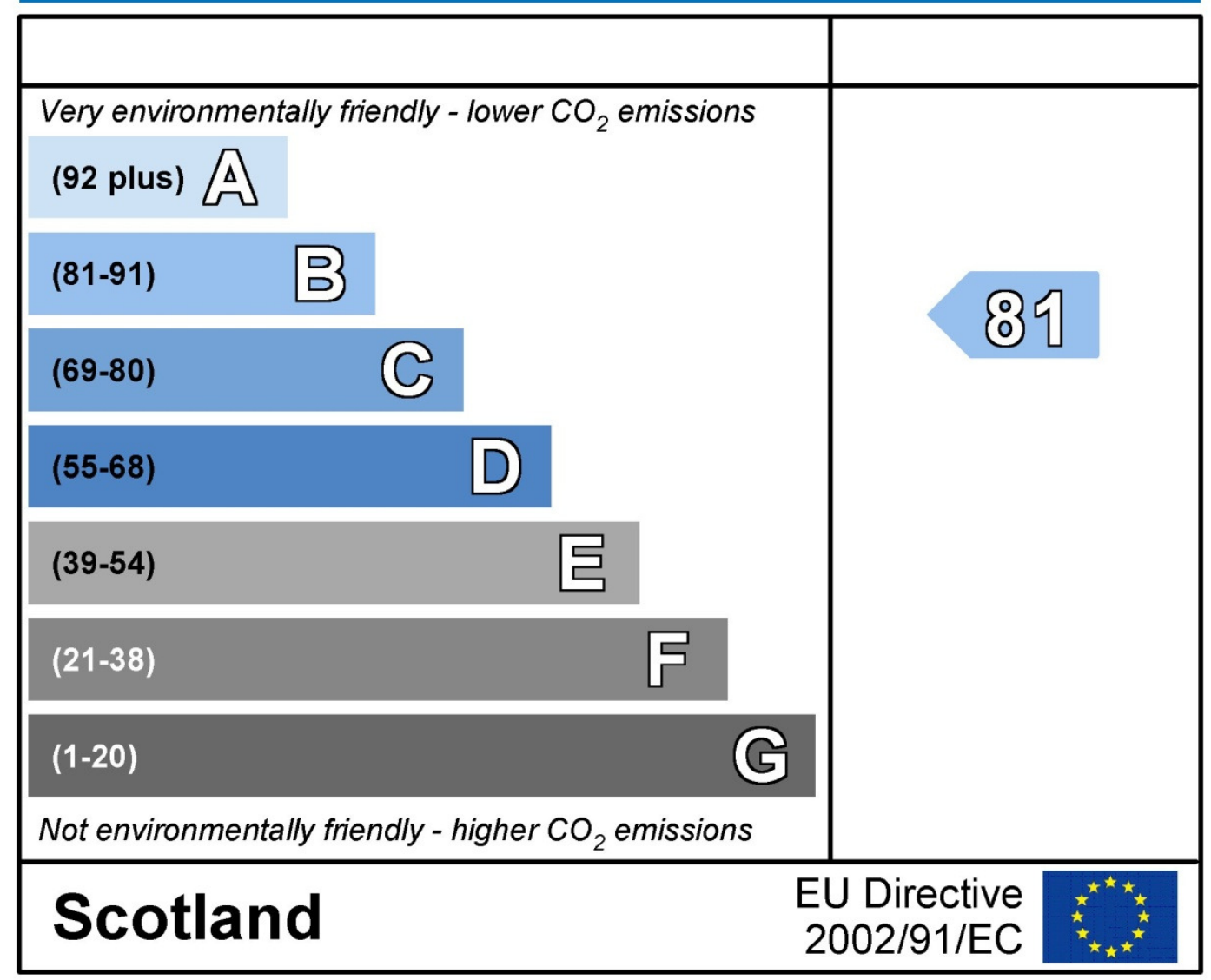




\section{Energy Efficiency Rating}

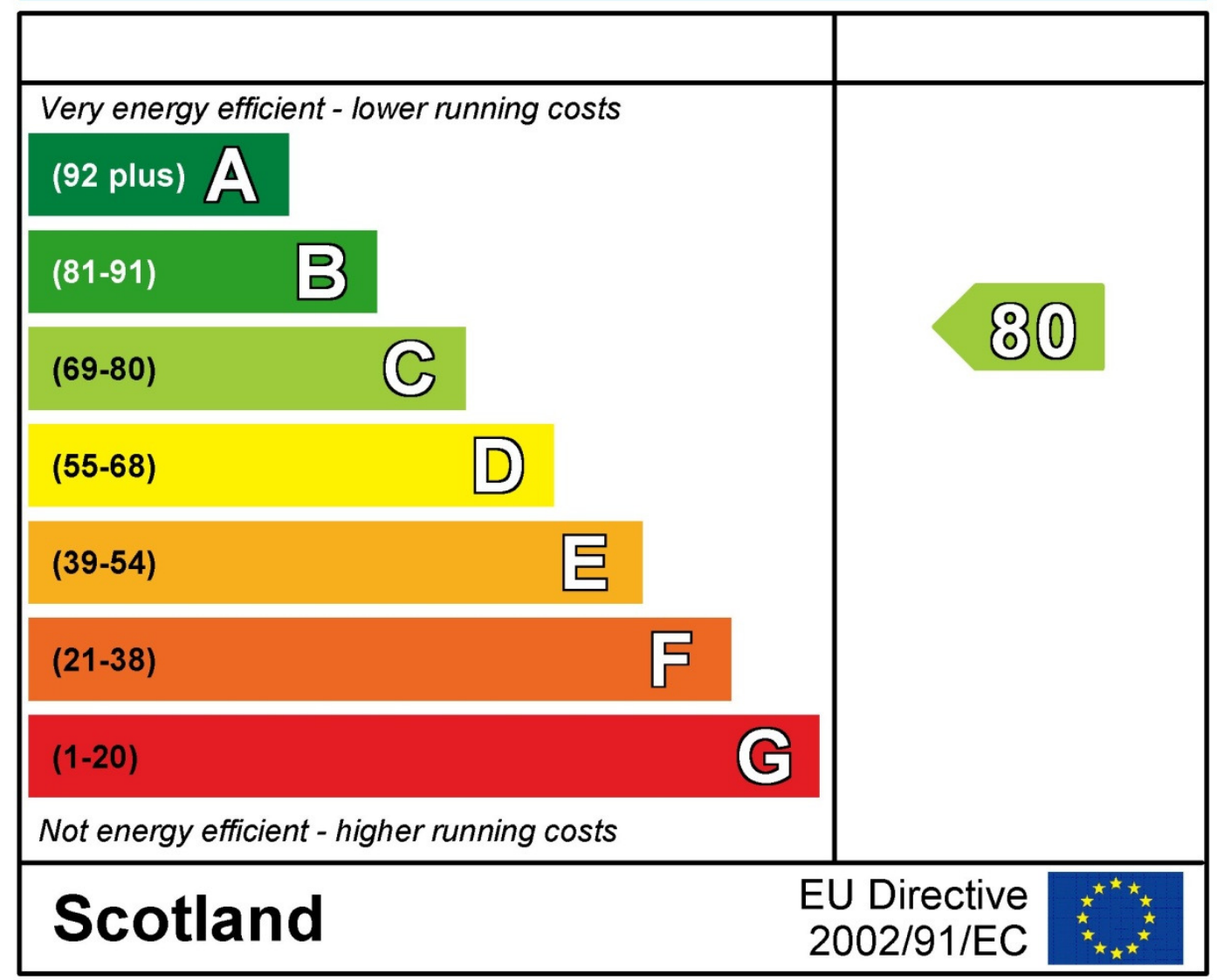

Figure 1 Sample SAP derived Energy Efficiency and Environmental Impact Ratings 
Table 1: STC Dwelling SAP Input Listings

\begin{tabular}{|l|c|c|c|c|}
\hline \multicolumn{1}{|c|}{ Element } & $\begin{array}{c}\text { Gross } \\
\text { area }\left[\mathbf{m}^{\mathbf{2}}\right]\end{array}$ & $\begin{array}{c}\text { Opening } \\
\mathbf{s}\left[\mathbf{m}^{\mathbf{2}}\right]\end{array}$ & $\begin{array}{c}\text { Net area } \\
{\left[\mathbf{m}^{\mathbf{2}}\right]}\end{array}$ & $\begin{array}{c}\mathbf{U} \text { value } \\
{\left[\mathbf{W} / \mathbf{m}^{2} \mathbf{K}\right]}\end{array}$ \\
\hline Ground floor & & & 52.00 & 0.22 \\
\hline First floor & & & 52.00 & 0.22 \\
\hline Walls & 143.00 & 24.50 & 118.50 & 0.30 \\
\hline Roof & 52.00 & 0.25 & 51.75 & 0.16 \\
\hline Doors & & & 7.60 & 3.00 \\
\hline Windows & & & 16.90 & 2.10 \\
\hline $\begin{array}{l}\text { Roof } \\
\text { windows }\end{array}$ & & & 0.25 & 2.30 \\
\hline
\end{tabular}

Table 2: Sap Table H2 - Annual Solar Radiation, $\mathrm{kWh} / \mathrm{m}^{2}$

\begin{tabular}{|l|c|c|c|c|c|}
\hline \multirow{2}{*}{$\begin{array}{c}\text { Tilt of } \\
\text { Collector }\end{array}$} & \multicolumn{5}{|c|}{ Orientation of Collector } \\
\cline { 2 - 6 } & South & SE/SW & E/W & NE/NW & North \\
\hline Horizontal & \multicolumn{5}{|c|}{933} \\
\hline $\mathbf{3 0}^{\circ}$ & 1042 & 997 & 886 & 962 & 709 \\
\hline $\mathbf{4 5}^{\circ}$ & 1023 & 968 & 829 & 666 & 621 \\
\hline $\mathbf{6 0}^{\circ}$ & 960 & 900 & 753 & 580 & 485 \\
\hline Vertical & 724 & 684 & 565 & 427 & 360 \\
\hline
\end{tabular}


Table 3: Available Energy at Inverter Output

\begin{tabular}{|l|c|c|c|c|}
\hline Method & $\begin{array}{c}\text { PV panel and } \\
\text { material }\end{array}$ & Inverter & $\begin{array}{c}\text { Yield } \\
{[\mathbf{k W h} / \mathbf{y}]}\end{array}$ & $\begin{array}{c}\text { SAP } \\
\text { rating }\end{array}$ \\
\hline PVSyst & $\begin{array}{c}\text { Sulfurcell SGC50 } \\
\text { HV-F (CIS) }\end{array}$ & $\begin{array}{c}\text { SMA Sunny- } \\
\text { Boy 2100GT }\end{array}$ & 1824 & B 82 \\
\hline SAP & N/A & N/A & 1667 & B 81 \\
\hline PVSyst & $\begin{array}{c}\text { Kyocera GHT200 } \\
\text { (Polycrystalline) }\end{array}$ & $\begin{array}{l}\text { SMA Sunny- } \\
\text { Boy 2100GT }\end{array}$ & 1632 & B 81 \\
\hline PVSyst & $\begin{array}{c}\text { Eurener PEPV } \\
200 \text { (Polycryst.) }\end{array}$ & $\begin{array}{c}\text { Suntechnics } \\
\text { STW1900 }\end{array}$ & 1514 & C 80 \\
\hline
\end{tabular}



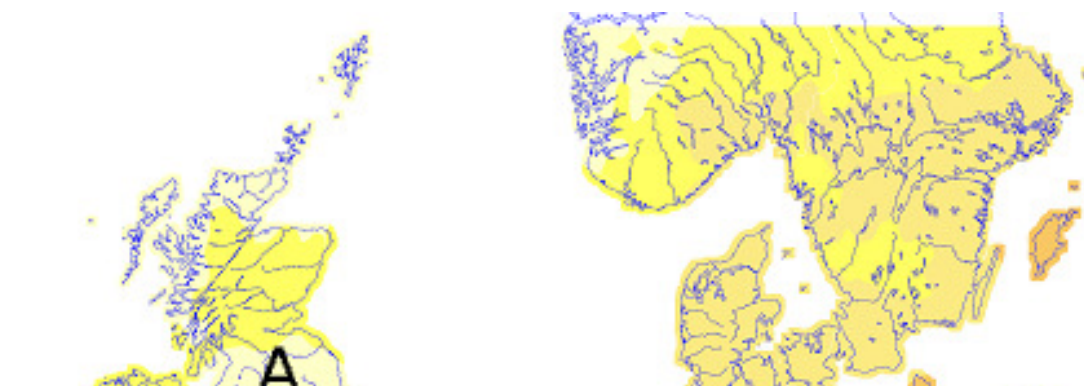

$1450-1550$
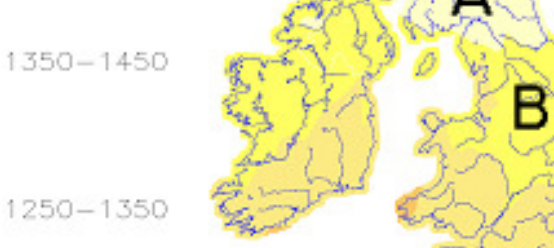

$1150-1250$

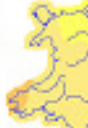

$1050-1150$

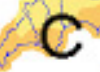

B

$950-1050$

$850-950$
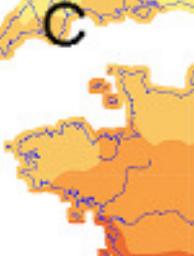

\begin{tabular}{|c|c|c|c|}
\hline $\begin{array}{l}\text { Locations used in } \\
\text { Detailed Simulation }\end{array}$ & $\begin{array}{c}\text { Location of } \\
\text { Weather Stations } \\
\text { utilised by } \\
\text { Meteonorm }\end{array}$ & \begin{tabular}{|c|} 
Solar \\
Availability - \\
Meteonorm \\
$\left(\mathrm{kWh} / \mathrm{m}^{2}\right)$
\end{tabular} & $\begin{array}{c}\text { Solar } \\
\text { Availability - } \\
\text { SAP } \\
\left(\mathbf{k W h} / \mathbf{m}^{2}\right)\end{array}$ \\
\hline A & $\begin{array}{l}\text { Eskdalemuir, } \\
\text { South Scotland }\end{array}$ & 917 & 1042 \\
\hline B & $\begin{array}{c}\text { Sheffield, } \\
\text { Northern England } \\
\text { - approximate } \\
\text { SAP } \\
\text { representative } \\
\text { location of the UK }\end{array}$ & 1013 & 1042 \\
\hline C & $\begin{array}{l}\text { Efford, South } \\
\text { England }\end{array}$ & 1225 & 1042 \\
\hline
\end{tabular}

Figure 2. European Radiation, annual mean 1981 - 2000. Weather Locations utilised in detailed simulation noted. Adapted from Source: (Meteonorm, 2009) 
Table 4: Results for several locations based upon $2 \mathrm{kWp}$ South Facing PV system at $30^{\circ}$

\begin{tabular}{|l|c|c|c|}
\hline $\begin{array}{c}\text { Calculation } \\
\text { methodology }\end{array}$ & Location & Inverter output [kWh/y] & SAP rating \\
\hline PVSyst & Efford & 1983 & B 83 \\
\hline SAP & Sheffield & 1667 & B 81 \\
\hline PVSyst & Sheffield & 1632 & B 81 \\
\hline PVSyst & Eskdalemuir & 1480 & B 80 \\
\hline
\end{tabular}

Table 5: Results for several locations and components based upon 2kWp South Facing PV system at $30^{\circ}$

\begin{tabular}{|l|c|c|c|c|}
\hline \multicolumn{1}{|c|}{$\begin{array}{c}\text { Method and } \\
\text { location }\end{array}$} & $\begin{array}{c}\text { PV panel and } \\
\text { material }\end{array}$ & Inverter & $\begin{array}{c}\text { Yield } \\
{[\mathbf{k W h} / \mathbf{l}]}\end{array}$ & $\begin{array}{c}\text { SAP } \\
\text { rating }\end{array}$ \\
\hline $\begin{array}{l}\text { PVSyst } \\
\text { (Efford) }\end{array}$ & $\begin{array}{c}\text { Sulfurcell } \\
\text { SGC50 HV-F } \\
\text { (CIS) }\end{array}$ & $\begin{array}{c}\text { SMA Sunny- } \\
\text { Boy 2100GT }\end{array}$ & 2183 & B 84 \\
\hline $\begin{array}{l}\text { PVSyst } \\
\text { (Sheffield) }\end{array}$ & $\begin{array}{c}\text { Sulfurcell } \\
\text { SGC50 HV-F } \\
\text { (CIS) }\end{array}$ & $\begin{array}{l}\text { SMA Sunny- } \\
\text { Boy 2100GT }\end{array}$ & 1824 & B 82 \\
\hline $\begin{array}{l}\text { SAP } \\
\text { (Sheffield) }\end{array}$ & N/A & N/A & 1667 & B 81 \\
\hline $\begin{array}{l}\text { PVSyst } \\
\text { (Sheffield) }\end{array}$ & $\begin{array}{c}\text { Kyocera } \\
\text { GHT200 } \\
\text { (Polycrystalline) }\end{array}$ & $\begin{array}{l}\text { SMA Sunny- } \\
\text { Boy 2100GT }\end{array}$ & 1632 & B 81 \\
\hline $\begin{array}{l}\text { PVSyst } \\
\text { (Sheffield) }\end{array}$ & $\begin{array}{c}\text { Eurener PEPV } \\
\text { 200 } \\
\text { (Polycrystalline) }\end{array}$ & $\begin{array}{c}\text { Suntechnics } \\
\text { STW1900 }\end{array}$ & 1514 & C 80 \\
\hline $\begin{array}{l}\text { PVSyst } \\
\text { (Eskdalemuir) }\end{array}$ & $\begin{array}{c}\text { Eurener PEPV } \\
\text { 200 } \\
\text { (Polycrystalline) }\end{array}$ & $\begin{array}{l}\text { Suntechnics } \\
\text { STW1900 }\end{array}$ & 1363 & C 80 \\
\hline
\end{tabular}


Table 6: Results for several PV pitch and azimuths based upon a 2kWp PV System in a Sheffield, UK location.

\begin{tabular}{|c|c|c|c|c|}
\hline Azimuth & PV Pitch & SAP - Yield [kWh/y] & PVSyst - Yield [kWh/y] & \% Difference \\
\hline $\mathbf{0}^{\circ}$ (South) & $0^{\circ}$ & 1493 & 1395 & 7 \\
\hline $\mathbf{0}^{\circ}$ (South) & $30^{\circ}$ & 1667 & 1632 & 2 \\
\hline $\mathbf{0}^{\circ}$ (South) & $60^{\circ}$ & 1536 & 1536 & 0 \\
\hline $\mathbf{0}^{\circ}$ (South) & $90^{\circ}$ & 1157 & 1143 & 1 \\
\hline $\mathbf{- 9 0}^{\circ}$ (West) & $30^{\circ}$ & 1418 & 1320 & 7 \\
\hline $\mathbf{- 9 0}^{\circ}$ (West) & $60^{\circ}$ & 1205 & 1132 & 6 \\
\hline $\mathbf{- 9 0}^{\circ}$ (West) & $90^{\circ}$ & 936 & 843 & 10 \\
\hline $\mathbf{9 0}^{\circ}$ (East) & $30^{\circ}$ & 1418 & 1325 & 7 \\
\hline $\mathbf{9 0}^{\circ}$ (East) & $60^{\circ}$ & 1205 & 1141 & 5 \\
\hline $\mathbf{9 0}^{\circ}$ (East) & $90^{\circ}$ & 904 & 852 & 6 \\
\hline $\mathbf{1 8 0}^{\circ}$ (North) & $30^{\circ}$ & 1134 & 973 & 14 \\
\hline $\mathbf{1 8 0}^{\circ}$ (North) & $60^{\circ}$ & 776 & 610 & 21 \\
\hline $\mathbf{1 8 0}^{\circ}$ (North) & $90^{\circ}$ & 576 & 444 & 23 \\
\hline
\end{tabular}

Table 7: SAP Table H1 - Default Collector Parameters. (IEA-SHC Figures in Brackets)

\begin{tabular}{|l|c|c|c|}
\hline $\begin{array}{l}\text { Collector } \\
\text { Type }\end{array}$ & $\eta_{\mathbf{0}}$ & $\mathbf{a}_{\mathbf{1}}$ & $\begin{array}{c}\text { Ratio of aperture area to gross } \\
\text { area }\end{array}$ \\
\hline $\begin{array}{l}\text { Evacuated } \\
\text { Tube }\end{array}$ & $\begin{array}{c}0.6 \\
(0.76)\end{array}$ & $\begin{array}{c}3 \\
(1.2)\end{array}$ & 0.72 \\
\hline $\begin{array}{l}\text { Flat Plate, } \\
\text { Glazed }\end{array}$ & $\begin{array}{c}0.75 \\
(0.78)\end{array}$ & $\begin{array}{c}6 \\
(3.2)\end{array}$ & 0.90 \\
\hline Unglazed & $\begin{array}{c}0.9 \\
(0.90)\end{array}$ & $\begin{array}{c}20 \\
(20)\end{array}$ & 1.00 \\
\hline
\end{tabular}


Table 8: SDHW results overview

\begin{tabular}{|c|c|c|c|c|c|c|}
\hline \multirow{2}{*}{ Solar collector } & \multirow{2}{*}{ Location } & \multirow{2}{*}{$\begin{array}{l}\text { Slope and } \\
\text { azimuth }\end{array}$} & \multicolumn{2}{|c|}{ Solar input [kWh] } & \multicolumn{2}{|c|}{$\begin{array}{c}\text { Water heater output } \\
\text { [kWh] }\end{array}$} \\
\hline & & & SAP & $\begin{array}{l}\text { TRN } \\
\text { SYS }\end{array}$ & SAP & $\begin{array}{l}\text { TRN } \\
\text { SYS }\end{array}$ \\
\hline SAP FP & Sheffield & $30^{\circ}, \mathrm{S}$ & 1186 & 1461 & 1924 & 1782 \\
\hline \multirow{3}{*}{ IEA Flat-Plate } & Sheffield & $30^{\circ}, \mathrm{S}$ & \multirow{3}{*}{1395} & 1840 & \multirow{3}{*}{1714} & 1488 \\
\hline & Eskdalemuir & $30^{\circ}, \mathrm{S}$ & & 1635 & & 1647 \\
\hline & Efford & $30^{\circ}, \mathrm{S}$ & & 2237 & & 1191 \\
\hline SAP ET & Sheffield & $30^{\circ}, \mathrm{S}$ & 1241 & 1548 & 1869 & 1714 \\
\hline \multirow{5}{*}{$\begin{array}{c}\text { IEA Evacuated } \\
\text { tube }\end{array}$} & Sheffield & $30^{\circ}, \mathrm{S}$ & \multirow{2}{*}{1530} & 2246 & \multirow{2}{*}{1580} & 1220 \\
\hline & Efford & $30^{\circ}, \mathrm{S}$ & & 2626 & & 965 \\
\hline & Sheffield & $45^{\circ}, \mathrm{S}$ & 1521 & 2344 & 1588 & 1141 \\
\hline & Sheffield & $60^{\circ}, \mathrm{S}$ & 1493 & 2371 & 1617 & 1110 \\
\hline & Sheffield & $90^{\circ}, \mathrm{S}$ & 1353 & 2184 & 1757 & 1199 \\
\hline
\end{tabular}


Table 9: Sigma House SAP Input Listings

\begin{tabular}{|l|c|c|c|c|}
\hline \multicolumn{1}{|c|}{ Element } & $\begin{array}{c}\text { Gross Area } \\
\left(\mathbf{m}^{\mathbf{2}}\right)\end{array}$ & $\begin{array}{c}\text { Openings } \\
\left(\mathbf{m}^{\mathbf{2}} \mathbf{)}\right.\end{array}$ & $\begin{array}{c}\text { Net Area } \\
\left(\mathbf{m}^{\mathbf{2}}\right)\end{array}$ & $\begin{array}{c}\mathbf{U}-\text { Value } \\
\left(\mathbf{W} / \mathbf{m}^{\mathbf{2}} \mathbf{K}\right)\end{array}$ \\
\hline Ground Floor & & & 33.13 & 0.13 \\
\hline Exposed Floor & 4.00 & & 4.00 & 0.13 \\
\hline Walls & 174.79 & 44.35 & 130.44 & 0.15 \\
\hline Roof (1) & 21.02 & & 21.02 & 0.13 \\
\hline Roof (2) & 16.17 & & 16.17 & 0.11 \\
\hline Doors & & & 1.89 & 2.00 \\
\hline Windows (1) & & & 42.46 & 0.70 \\
\hline Windows (2) & & & & 1.40 \\
\hline Roof Windows & & & 0.25 & 2.30 \\
\hline
\end{tabular}

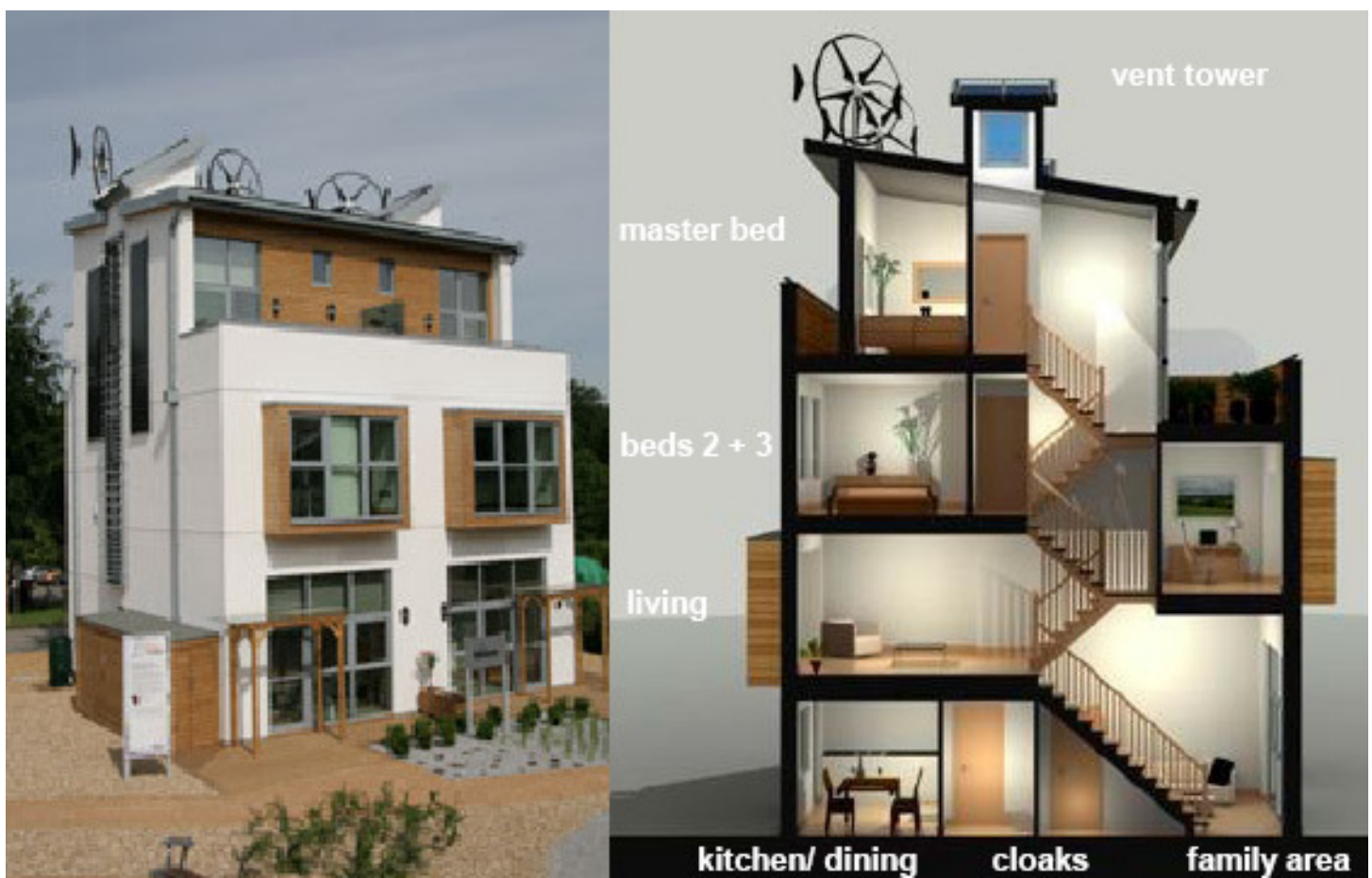

Figure 3: Stewart Milne Sigma Home - BRE Innovation Park, Garston, UK. Adapted from source: Stewart Milne, 2008 


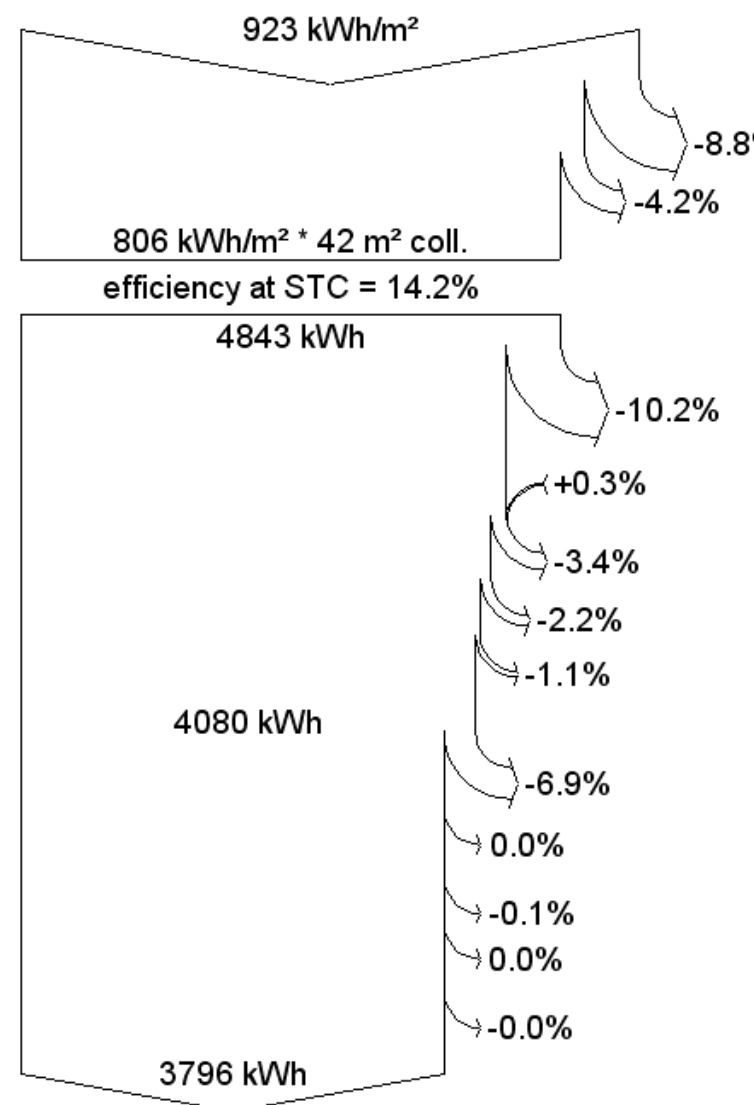

Horizontal global irradiation

Global incident in coll. plane

IAM factor on global

Effective irradiance on collectors

PV conversion

efficiency at STC $=14.2 \%$

PV loss due to irradiance level

PV loss due to temperature

Module quality loss

Module array mismatch loss

Ohmic wiring loss

Array virtual energy at MPP

Inverter Loss during operation (efficiency)

Inverter Loss over nominal inv. power

Inverter Loss due to power threshold

Inverter Loss over nominal inv. voltage

Inverter Loss due to voltage threshold

Available Energy at Inverter Output

Figure 4. Sankey Diagram detailing PV Production for Sigma Home. 
Table 10: SAP Table 1, highlighting the relationship between TFA and hot water energy requirements

\begin{tabular}{|c|c|c|c|}
\hline $\begin{array}{c}\text { Floor } \\
\text { Area } \\
\text { TFA }\left(\mathbf{m}^{2}\right)\end{array}$ & $\begin{array}{c}\mathbf{( a )} \\
\text { Hot water } \\
\text { usage } \\
\mathbf{V}_{\mathbf{d}} \text { (litres/day) }\end{array}$ & $\begin{array}{c}\mathbf{( b )} \\
\text { Energy content of } \\
\text { water used } \\
\mathbf{( k W h / y e a r )}\end{array}$ & $\begin{array}{c}\mathbf{( c )} \\
\text { Distribution } \\
\text { loss } \\
\text { (kWh/year) }\end{array}$ \\
\hline 30 & 63 & 1146 & 202 \\
\hline 40 & 71 & 1293 & 228 \\
\hline 50 & 79 & 1437 & 254 \\
\hline 60 & 87 & 1577 & 278 \\
\hline 70 & 95 & 1713 & 302 \\
\hline 80 & 102 & 1846 & 326 \\
\hline 90 & 109 & 1976 & 349 \\
\hline 100 & 116 & 2102 & 371 \\
\hline 110 & 123 & 2225 & 393 \\
\hline
\end{tabular}

